\title{
Methodological triangulation of the student's use of recorded lectures
}

Citation for published version (APA):

Gorissen, P., Van Bruggen, J., \& Jochems, W. (2013). Methodological triangulation of the student's use of recorded lectures. International Journal of Learning Technology, 8(1), 20-40.

https://doi.org/10.1504/IJLT.2013.052825

\section{DOI:}

10.1504/IJLT.2013.052825

Document status and date:

Published: 01/01/2013

Document Version:

Other version

Document license:

CC BY-NC-ND

Please check the document version of this publication:

- A submitted manuscript is the version of the article upon submission and before peer-review. There can be important differences between the submitted version and the official published version of record. People interested in the research are advised to contact the author for the final version of the publication, or visit the DOI to the publisher's website.

- The final author version and the galley proof are versions of the publication after peer review.

- The final published version features the final layout of the paper including the volume, issue and page numbers.

Link to publication

\section{General rights}

Copyright and moral rights for the publications made accessible in the public portal are retained by the authors and/or other copyright owners and it is a condition of accessing publications that users recognise and abide by the legal requirements associated with these rights.

- Users may download and print one copy of any publication from the public portal for the purpose of private study or research.

- You may not further distribute the material or use it for any profit-making activity or commercial gain

- You may freely distribute the URL identifying the publication in the public portal.

If the publication is distributed under the terms of Article 25fa of the Dutch Copyright Act, indicated by the "Taverne" license above, please follow below link for the End User Agreement:

https://www.ou.nl/taverne-agreement

Take down policy

If you believe that this document breaches copyright please contact us at:

pure-support@ou.nl

providing details and we will investigate your claim.

Downloaded from https://research.ou.nl/ on date: 26 Apr. 2023 
Title

Methodological triangulation of the students' use of recorded lectures

\title{
Authors
}

Pierre Gorissen.

Jan van Bruggen

Wim Jochems

\section{Addresses}

Fontys University of Applied Sciences, P.O. Box 347, 5600AH, Eindhoven, The Netherlands Open University of the Netherlands, P.O. Box 2960, 6401DL, Heerlen, The Netherlands Eindhoven University of Technology, P.O. Box 513, 5600MB, Eindhoven, The Netherlands

\section{Journal}

International Journal of Learning Technology, 2013, 8, (1), 20-40

\begin{abstract}
:
A lot of research into the use of recorded lectures has been done by using surveys or interviews. We will show that triangulation of multiple data sources is needed. We will discuss how students use recorded lectures according to their self-report and what actual usage of the recorded lectures can be derived from the data on the system. We will present the data collections and cover areas where the data can be triangulated to increase the credibility of the results or to question the students' responses. The triangulation shows that we lack data for a number of areas. We will need high-quality surveys and interviews combined with the log data to get a complete picture. We need to be able to link data sets together based on the identification of the individual students, which might raise privacy issues.
\end{abstract}

\section{APA}

Gorissen, P, Van Bruggen, J. \& Jochems, W.(2013) Methodological triangulation of the students' use of recorded lectures. International Journal of Learning Technology, 2013 (8) 2040

DOI: $\underline{10.1504 / \mathrm{IJLT} .2013 .052825}$ 